\title{
Mitogen responsiveness in viral hepatitis and chronic active hepatitis: the role of reversible suppressive influences
}

\author{
C FEIGHERY, J F GREALLY, AND D G WEIR* \\ From the Department of Medicine and Immunology, Trinity College, Dublin
}

SUMMARY Depressed phytohaemagglutinin and concanavalin-A responsiveness was found in patients with acute viral hepatitis (VH) when a suboptimal mitogen stimulus was used. Normal responsiveness was observed with optimal mitogen stimulation. These findings were independent of extrinsic serum inhibitors. When viral hepatitis lymphocytes were preincubated before mitogen addition an enhanced responsiveness similar to the control group occurred. These in vitro findings are in favour of a primary defect in lymphoproliferation in viral hepatitis and do not suggest the presence of reversible suppressive influences such as an excess of short-lived suppressor cells or the presence of cell bound inhibitors. In chronic active hepatitis (CAH) lymphoproliferation induced by immediate mitogen stimulation was similar to control studies. However when CAH cells were preincubated before mitogen addition, enhanced responsiveness significantly greater than in controls occurred. It is suggested that suppressive influences are present in $\mathrm{CAH}$ and that their effect can be reversed by cellular preincubation.

In acute viral hepatitis mitogen induced lymphoproliferation is frequently depressed, ${ }^{1-3}$ but the cause of this depression is disputed. In some studies hyporesponsiveness was found in lymphocyte cultures performed in the absence of autologous serum $^{13}$ and an intrinsic lymphocyte defect was implicated. Others have reported normal responsiveness in similar cultures ${ }^{4}$ and claimed that the depressed lymphoproliferation in viral hepatitis is due to the serum inhibitory factors which have been described in this disease. ${ }^{3-6}$ Mitogen studies in chronic active hepatitis (CAH) have also produced conflicting findings: both normal ${ }^{4}{ }^{7-9}$ and depressed responsiveness ${ }^{10-12}$ have been reported. Serum factors which depress mitogen stimulation have also been found in $\mathrm{CAH}^{45}$

In other disease states, the adsorption of inhibitory factors to mononuclear cell surfaces has been described and this was additional to the presence of similar unbound factors in the serum. ${ }^{13-15}$ In these reports, an enhanced lymphoproliferative capacity was observed after the incubation of these cells at $37^{\circ} \mathrm{C}$. In viral hepatitis and $\mathrm{CAH}$, improved

*Address for reprint requests: Professor D Q Weir, Sir Patrick Duns Hospital, Dublin 2.

Received for public?tion 18 April 1980 sheep erythrocyte rosetting has been described after similar incubation ${ }^{16}$ but the effect on mitogen responsiveness has not previously been investigated.

In this study of mitogen induced lymphoproliferation in viral hepatitis and $\mathrm{CAH}$, the influence of unbound serum inhibitory factors was avoided by culturing mononuclear cells washed free of autologous serum. Additional cultures were performed using cells which were preincubated before mitogen stimulation in the expectation that this manoeuvre would abrogate the effect of cell-bound inhibitors or other possible suppressive influences. ${ }^{17}$ Three mitogens were used, phytohaemagglutinin (PHA), concanavalin-A (Con-A), and pokeweed mitogen (PWM.) A range of concentrations was used, as it has been reported that hyporesponsiveness may be best demonstrated with a suboptimal mitogen stimulus. $^{13}{ }^{18-20}$

When suboptimally stimulated, the viral hepatitis patients were found to be significantly hyporesponsive to PHA and Con-A. The lymphoproliferation observed in the CAH group did not differ significantly from the controls studied. In the experiments in which cells were preincubated before mitogen stimulation, the control and both patient groups demonstrated significantly enhanced proliferation. The degree of enhancement found in the viral 
hepatitis patients was no different from the controls, whereas the CAH patients developed significantly greater enhancement.

\section{Methods}

\section{PA TIENTS}

Thirty patients were studied. Nineteen had acute viral hepatitis, 15 of whom were studied within five weeks of the onset of their symptoms. Three patients were seropositive for the hepatitis-B surface antigen (HBsAg) as measured by reverse passive haemagglutination (Wellcome Reagents). The mean age was 23 years (range 5-60 years).

Eleven patients with chronic active hepatitis (eight females) were studied. The diagnosis was based on established histological criteria ${ }^{21}$ in conjunction with typical clinical and laboratory parameters $^{22}$ in all patients. One patient was persistently positive for HBsAg. Seven were being treated with steroids at the time of study (prednisolone 7.5$45 \mathrm{mg} /$ day). The mean age was 42 years (range 17-62 years).

\section{CONTROLS}

The control group consisted of 32 normal subjects, mean age 40 years (range 18-71 years). In individual studies, sex and age-matched controls were used.

\section{LYMPHOCYTE CULTURES}

Methods similar to those previously described were used. ${ }^{23}$ Mononuclear cells were obtained from heparinised blood by plasma gel (Laboratoire Roger Bellon) sedimentation and density gradient separation using Ficoll-Hypaque. ${ }^{24}$ Cells were then washed twice with $25 \mathrm{ml}$ RPMI 1640 (Gibco, Biocult) and resuspended in RPMI supplemented with $10 \%$ fetal calf serum and $100 \mathrm{U} / \mathrm{ml}$ penicillin-strepomtycin solution (Gibco, Biocult).

$10^{5}$ cells in $0.2 \mathrm{ml}$ of culture medium were then added to the wells of a microculture plate (Sterilin microtitre F) and incubated at $37^{\circ} \mathrm{C}$ in a humidified $5 \% \mathrm{CO}_{2} /$ air atmosphere. All cultures were performed in triplicate and cells were incubated in the presence or absence of mitogen. Three mitogens were used: phytohaemagglutinin (PHA-P, Bacto Difco) with a concentration range of 1.6 to $100 \mu \mathrm{g} / \mathrm{ml}$; concanavalin-A (Con-A, Pharmacia) with a concentration range of 1 to $25 \mu \mathrm{g} / \mathrm{ml}$; and pokeweed mitogen (PWM, Grand Island Biological Co.) with a concentration range of $0 \cdot 1$ to $1000 \mu \mathrm{g} / \mathrm{ml}$. The PHA and Con-A cultures were terminated after 48 hours of incubation and PWM cultures after 120 hours.

Four hours before the end of the incubation period, $0.3 \mu \mathrm{Ci}$ of $\left({ }^{3} \mathrm{H}\right)$ thymidine (sp.act. $2.0 \mathrm{mCi} /$ $\mathrm{mM}$; Radiochemicals) was added to each culture well. The contents of each well were then harvested onto glass fibre discs (Whatman), washed in 10\% trichloracetic acid, and dehydrated with methanol. The incorporation of radioactive thymidine in the dried discs was measured by liquid scintillation counting (Tricarb, Packard).

\section{PRE-MITOGEN INCUBATION STUDIES}

In a further series of experiments cells were cultured for 24 hours before Con-A stimulation. These cultures $\left(t_{24}\right)$ were compared with cultures to which Con- $\mathrm{A}$ was added at the commencement $\left(\mathrm{t}_{0}\right)$. In each instance the culture was terminated 48 hours after the addition of mitogen. The $t_{24}$ counts per minute (ct $/ \mathrm{min}$ ) were expressed as a ratio of the $t_{0} \mathrm{ct} / \mathrm{min}$.

ANALYSIS OF DATA

Student's $t$ test for paired and non-paired data were used to analyse the statistical significance of the results.

\section{Results}

STUDIES IN VIRAL HEPATITIS PATIENTS

Ten viral hepatitis patients were studied using PHA, Con-A, and PWM as mitogen stimuli in lymphocyte cultures. Their responses were compared with those of 41 control subjects.

\section{PHA}

Five concentrations of PHA were used (Fig. 1). At low PHA concentrations $(3 \cdot 1$ and $6 \cdot 3 \mu \mathrm{g} / \mathrm{ml})$

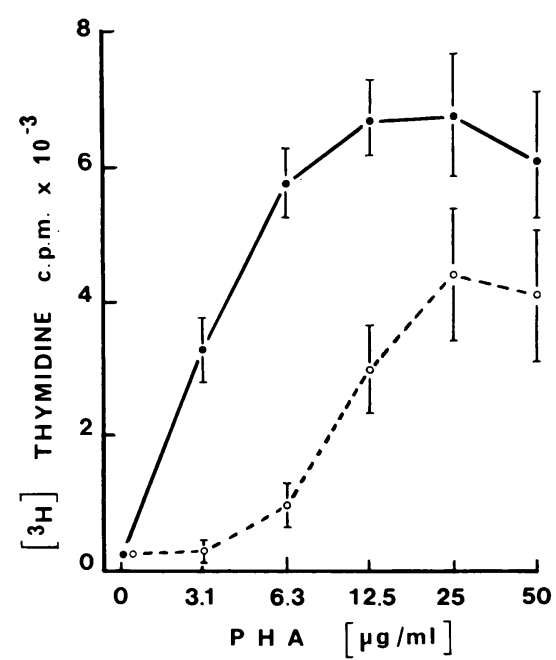

Fig. 1 Lymphocyte transformation after $P H A$ stimulation in 41 control studies ( $-(-)$ ) and in 10 viral hepatitis patients $(\bigcirc---\bigcirc)$. Points represent means and bars show standard errors. 


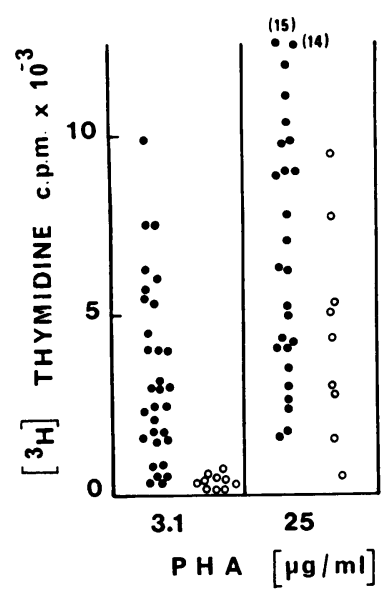

Fig. 2 Scatter diagram representation of lymphocyte transformation after PHA stimulation in controls (O) and in viral hepatitis patients (O). A suboptimal $(3 \cdot 1 \mu \mathrm{g} / \mathrm{ml})$ and an optimal $(25 \mu \mathrm{g} / \mathrm{ml})$ concentration of PHA are shown.

highly significant hyporesponsiveness was observed in the viral hepatitis patients $(P<0.001)$. At higher concentrations $(25$ and $50 \mu \mathrm{g} / \mathrm{ml})$ the difference was no longer significant $(\mathrm{P}<0.05$ and $\mathrm{P}<0.2$ respectively). Figure 2 shows the results of the PHA concentrations $3 \cdot 1$ and $25 \mu \mathrm{g} / \mathrm{ml}$ as a scatter diagram. When the low PHA concentration (3.1 $\mu \mathrm{g} / \mathrm{ml})$ was used, the viral hepatitis patients showed only a minor proliferative response, whereas at an optimal concentration $(25 \mu \mathrm{g} / \mathrm{ml})$, the majority demonstrated normal isotope incorporation.

\section{Con- $A$}

The viral hepatitis patients were also hyporesponsive to Con-A stimulation (Fig. 3). The lowest Con-A concentration $(2 \mu \mathrm{g} / \mathrm{ml})$ resulted in minimal proliferation in the control and patient groups. At the higher concentrations $(5.8$ and $10 \mu \mathrm{g} / \mathrm{ml})$ the viral hepatitis patients responsiveness was significantly depressed $(\mathbf{P}<0.025 ; \quad \mathbf{P}<0.005 ; \quad \mathbf{P}<0.025$ respectively).

\section{$P W M$}

In the PWM stimulation experiments, the lymphocyte cultures were incubated for six days and under these culture conditions, the viral hepatitis patients' responses did not differ from the controls (Fig. 4).

\section{STUDIES IN CHRONIC ACTIVE HEPATITIS}

PATIENTS

Eleven patients with CAH were studied. Although considerable variation in lymphoproliferation was observed, the mean responsiveness of the $\mathrm{CAH}$

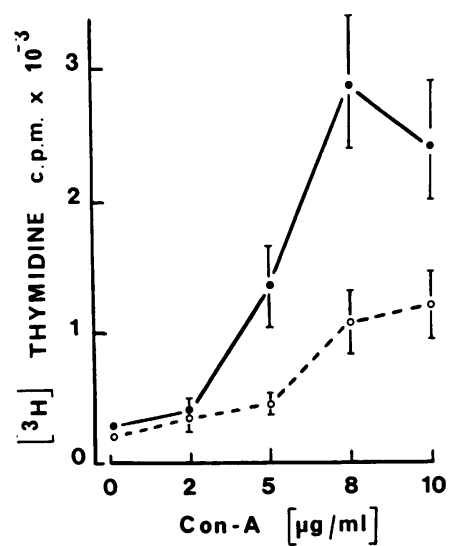

Fig. 3 Lymphocyte transformation after Con- $A$ stimulation in 10 control studies (๑- - $)$ ) and in 10 viral hepatitis patients $\left(\bigcirc_{---} \bigcirc\right)$. Points represent means and bars show standard errors.

patients to PHA (Table 1), Con-A (Table 2), and PWM (results not shown) did not differ significantly from the controls. Three of the CAH group were young $\mathrm{HBsAg}$ negative females, with multiple autoantibodies, raised gamma globulin, typical liver histology, and clinically aggressive disease requiring immunosuppressive therapy: their responses were very similar to young healthy controls. A fourth female $\mathrm{CAH}$ patient with clinically inactive disease was studied serially during a six week period (Fig. 5). The initial culture resulted in supranormal lymphocyte proliferation. Three weeks later this enhanced responsiveness was less apparent but,

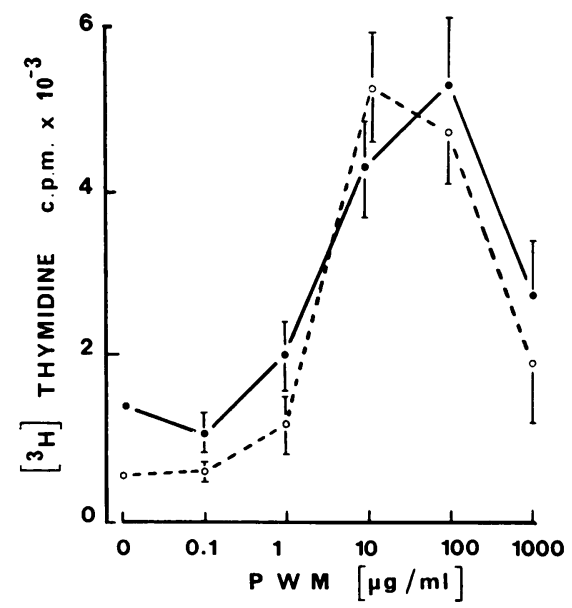

Fig. 4 Lymphocyte transformation after PWM stimulation in 10 control studies ( $\left.--0^{-}\right)$and in 10 viral hepatitis patients $\left(\bigcirc_{---} \bigcirc\right)$. Points represent means and bars show standard errors. 
Table $1 P H A$ responsiveness in control subjects and patients with chronic active hepatitis

\begin{tabular}{|c|c|c|c|c|c|}
\hline \multirow{2}{*}{$\begin{array}{l}P H A \\
(\mu g / m l)\end{array}$} & \multicolumn{2}{|c|}{ Controls } & \multicolumn{2}{|c|}{ Chronic active hepatitis } & \multirow[t]{2}{*}{ Significance $\ddagger$} \\
\hline & No. & $C P M \pm S E M^{*} \dagger$ & No. & $C P M \pm S E M$ & \\
\hline $\begin{array}{r}0 \\
1 \cdot 6 \\
3 \cdot 1 \\
6 \cdot 3 \\
12 \cdot 5 \\
25 \cdot 0 \\
100 \cdot 0\end{array}$ & $\begin{array}{l}41 \\
24 \\
31 \\
40 \\
38 \\
26 \\
28\end{array}$ & $\begin{array}{r}259 \pm 17 \\
1319 \pm 213 \\
3352 \pm 440 \\
5758 \pm 514 \\
6697 \pm 587 \\
6896 \pm 750 \\
4006 \pm 494\end{array}$ & $\begin{array}{r}12 \\
11 \\
10 \\
12 \\
8 \\
6 \\
8\end{array}$ & $\begin{array}{r}285 \pm 38 \\
903 \pm 277 \\
2375 \pm 719 \\
5849 \pm 1510 \\
6342 \pm 2182 \\
7994 \pm 3426 \\
4948 \pm 1679\end{array}$ & NS \\
\hline
\end{tabular}

* Mean $\left({ }^{3} \mathbf{H}\right)$ thymidine incorporation in counts per minute.

+ Standard error of the mean.

$\ddagger$ Analysed by Student's $t$ test for non-paired data.

NS: not significant.

Table 2 Con-A responsiveness in control subjects and patients with chronic active hepatitis

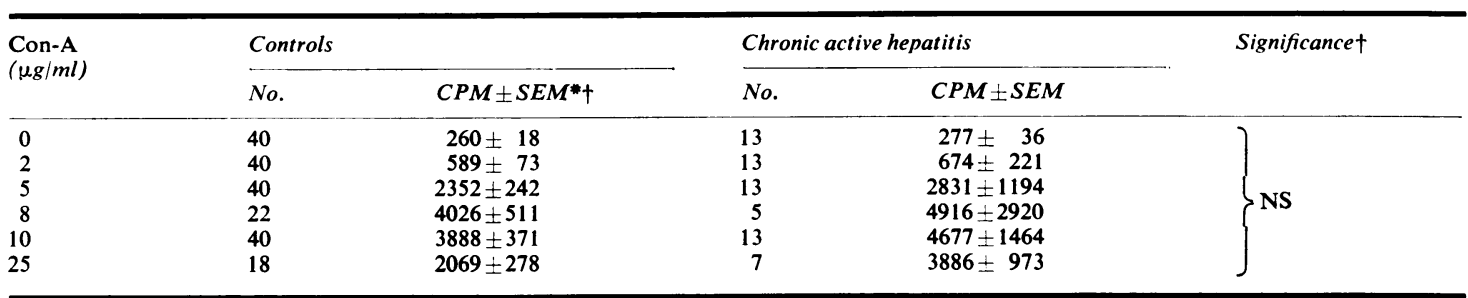

*Mean $\left({ }^{3} \mathrm{H}\right)$ thymidine incorporation in counts per minute.

†Standard error of the mean.

$¥$ Analysed by Student's $t$ test.

NS: not significant.

when a third culture was performed after a further three week interval, the patient demonstrated minimal lymphoproliferation only. This finding could not be explained by extrinsic factors such as loss of mitogen potency. The results of seven studies of a male control subject conducted over a six month period are also illustrated for comparison.

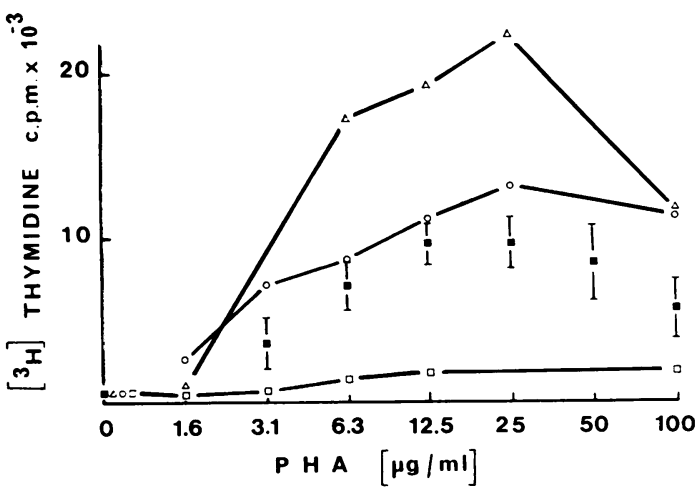

Fig. 5 Serial PHA induced lymphocyte transformation studies in patient $S C$ with chronic active hepatitis. The mean response of three sequential studies are represented by $\triangle, \bigcirc$, and $\square$ respectively. Seven repeated cultures in a male control subject are shown ( $\square$ ) and bars indicate standard errors.
PRE-MITOGEN INCUBATION STUDIES

The effect of a 24 hour incubation of cells before Con-A stimulation was examined (Table 3). In normal controls $\mathrm{t}_{24} / \mathrm{t}_{0}$ ratios of $5 \cdot 1$ (Con-A $1 \mu \mathrm{g} / \mathrm{ml}$ ), $2.5($ Con-A $2 \mu \mathrm{g} / \mathrm{ml}), 2 \cdot 2$ (Con-A $5 \mu \mathrm{g} / \mathrm{ml})$, and $1 \cdot 3$ (Con-A $10 \mu \mathrm{g} / \mathrm{ml}$ ) were found. This represented a significantly increased response at all four Con-A concentrations: $1,2,5 \mu \mathrm{g} / \mathrm{ml}(\mathrm{P}<0.001)$ and 10 $\mu \mathrm{g} / \mathrm{ml}(\mathbf{P}<0.005)$. The CAH patients studied also demonstrated enhanced responses but their ratios of enhancement $\left(t_{24} / t_{0}\right)$ were greater than the controls at all Con-A concentrations and this was significant with Con-A 5 and $10 \mu \mathrm{g} / \mathrm{ml}(\mathrm{P}<0.005)$. Moreover, the $t_{24} / t_{0}$ ratios of the total $23 \mathrm{CAH}$ patient experiments were significantly greater $(P<0.025)$ than the 110 control experiments.

In similar experiments the proliferative responses of $11 \mathrm{VH}$ patients were investigated after a 24 hour incubation (Table 4). This resulted in significantly improved responses but this was not different from the control group.

\section{Discussion}

In this study, viral hepatitis patients demonstrated significant hyporesponsiveness to PHA and Con-A stimulation and this finding could not be explained by serum inhibitory factors, as these experiments 
Table 3 Con- $A$ addition at start of culture $\left(t_{0}\right)$ or after 24 hours $\left(t_{24}\right)$ : control subjects compared with chronic active hepatitis patients

\begin{tabular}{|c|c|c|c|c|c|c|c|}
\hline \multirow{2}{*}{$\begin{array}{l}\text { Con-A } \\
(\mu g / m l)\end{array}$} & \multicolumn{3}{|l|}{ Controls } & \multicolumn{3}{|c|}{ Chronic active hepatitis } & \multirow[t]{2}{*}{ Significance $\ddagger$} \\
\hline & $t_{0}^{*}$ & $t_{24}$ & $t_{24} / t_{0} \dagger$ & $t_{0}$ & $t_{24}$ & $t_{\mathbf{2 4}} / t_{0}$ & \\
\hline $\begin{array}{r}0 \\
1 \\
2 \\
5 \\
10\end{array}$ & $\begin{array}{r}186 \pm 17 \\
241 \pm 25 \\
726 \pm 96 \\
2333 \pm 254 \\
4388 \pm 542\end{array}$ & $\begin{array}{r}190 \pm 12 \\
977 \pm 253 \\
2205 \pm 300 \\
4682 \pm 491 \\
5955 \pm 844\end{array}$ & $\begin{array}{l}1 \cdot 2 \pm 0 \cdot 1 \\
5 \cdot 1 \pm 1 \cdot 3 \\
2 \cdot 5 \pm 0 \cdot 4 \\
2 \cdot 2 \pm 0 \cdot 2 \\
1 \cdot 3 \pm 0 \cdot 1\end{array}$ & $\begin{array}{rr}213 \pm & 34 \\
252 \pm & 53 \\
436 \pm 126 \\
1403 \pm 616 \\
3640 \pm 1115\end{array}$ & $\begin{array}{r}255 \pm 44 \\
1410 \pm 616 \\
1924 \pm 610 \\
4359 \pm 1317 \\
7183 \pm 1813\end{array}$ & $\begin{array}{l}1 \cdot 3 \pm 0 \cdot 1 \\
7 \cdot 7 \pm 4 \cdot 9 \\
6 \cdot 4 \pm 2 \cdot 9 \\
6 \cdot 2 \pm 2 \cdot 7 \\
2 \cdot 4 \pm 0 \cdot 5\end{array}$ & $\begin{array}{l}P>0.4 \\
P>0.4 \\
P>0.05 \\
P<0.005 \\
P<0.005\end{array}$ \\
\hline
\end{tabular}

*Mean $\left({ }^{3} \mathrm{H}\right)$ thymidine incorporation in ct/min $\pm S E M$ in $t_{0}$ and $t_{24}$ cultures.

†The $t_{24} \mathrm{ct} / \mathrm{min}$ was expressed as a ratio of the $t_{0} \mathrm{ct} / \mathrm{min}$.

$¥$ The patients' $t_{24} / t_{0}$ ratios were compared with the control values and the data analysed by non-paired Student's $t$ test.

Table 4 Con- $A$ addition at start of culture $\left(t_{20}\right)$ or after 24 hours $\left(t_{24}\right)$ : control subjects compared with viral hepatitis patients

\begin{tabular}{|c|c|c|c|c|c|}
\hline \multirow[t]{2}{*}{ Con- $A$} & \multicolumn{2}{|c|}{ Controls } & \multicolumn{2}{|c|}{ Viral hepatitis } & \multirow[b]{2}{*}{ Significance $\dagger$} \\
\hline & No. & $t_{24} / t_{0}^{*}$ & No. & $t_{24} / t_{0}$ & \\
\hline $\begin{array}{r}0 \\
2 \\
5 \\
10\end{array}$ & $\begin{array}{l}30 \\
30 \\
23 \\
17\end{array}$ & $\begin{array}{l}1 \cdot 2 \pm 0.1 \\
2.5-0.4 \\
2 \cdot 2-0.2 \\
1.3-0.1\end{array}$ & $\begin{array}{l}11 \\
11 \\
11 \\
11\end{array}$ & $\begin{array}{l}0.9 \pm 0.1 \\
2.3-0.3 \\
1.8-0.2 \\
1.3-0.1\end{array}$ & $\{N S$ \\
\hline
\end{tabular}

*The $t_{24} \mathrm{ct} / \mathrm{min}$ was expressed as ratio of the $t_{0} \mathrm{ct} / \mathrm{min}$.

†The patients' $t_{24} / t_{0}$ ratios were compared with the control values and the data analysed by non-paired Student's $t$ test. NS: not significant.

were conducted in the absence of autologous serum. This impaired proliferative ability was most apparent when suboptimal concentrations of mitogen were used. Similar findings with suboptimal stimulation have been reported in other diseases including systemic lupus erythematosus (SLE) ${ }^{13} 18$ primary biliary cirrhosis, ${ }^{19}$ and ataxia telangiectasia. ${ }^{20}$ It would appear that more subtle defects in blastogenic capabilities can be detected by low concentrations of mitogen, whereas higher mitogen concentrations can overcome the inhibitory or deficiency factors involved. The proliferative response induced by PWM showed no difference between the viral hepatitis and control groups. This finding may be explained by the prolongation of PWM stimulated cultures to six days. Willems et al. ${ }^{1}$ also described VH hyporesponsiveness to PHA which was evident in three day cultures but not seen in six day cultures. The normal response induced by PWM might also be due to the different stimulatory capacity of this mitogen ${ }^{25}$, but this possibility was not analysed in these data.

The finding of mitogen hyporesponsiveness in viral hepatitis is in agreement with earlier reports. ${ }^{13}$ The normal response reported by Wands et al. ${ }^{4}$ may be explained by their failure to use a suboptimal mitogen stimulus. The duration of this hyporesponsiveness is not known but it may last as long as 10 weeks. $^{3}$ The three patients studied serially in these experiments all showed a definite improvement in proliferative capacity, indicating a return to normal reactivity.
In cultures performed in the absence of autologous serum, the CAH patients' lymphocyte response to PHA, Con-A, and PWM was similar to that observed in the controls. This finding is in agreement with the reports of some authors; $;^{\mathbf{4}-9}$ but in conflict with others. ${ }^{10-12}$ However, strict comparisons are difficult. In most of these studies the majority of the patients were $\mathrm{HBsAg}$ positive 7811 and, in some, autologous serum was present in the culture system. ${ }^{71} \mathrm{HBsAg}$ positive CAH is now considered to be a disease entity distinct from $\mathrm{HBsAg}$ negative $\mathrm{CAH}^{26}{ }^{27}$ and the heterogeneity of this latter group has also been recognised. ${ }^{28}$ All but one of the 11 patients in this study were $\mathrm{HBsAg}$ negative and when analysed separately their responses were still not significantly different from the control group.

Within the CAH group, considerable variation in mitogen responsiveness was observed, similar to the variation seen in the control subjects. However, in addition, the results of one patient studied serially suggests that exaggerated changes in lymphoproliferation may occur in CAH. Some fluctuation in responsiveness can be expected in serial lymphocyte blastogenesis studies. ${ }^{29}{ }^{30}$ Nonetheless, changes observed in this patient seemed in excess of this and were certainly greater than that of a normal subject also serially studied. During the six week study period, the patient's liver disease remained clinically stable. This variation may represent dynamic events in lymphocyte populations in $\mathrm{CAH}$, and serial variations in lymphocytotoxic activity and $T$ cell numbers have also been described in this disease. ${ }^{31}$ 
Seven of the $\mathrm{CAH}$ patients were being treated with prednisolone but this did not seem to inhibit their proliferative capacity. Other studies have reported similar findings. ${ }^{41}$ On the contrary, it has been suggested that mitogen responsiveness in $\mathrm{CAH}$ improved after immunosuppressive therapy.11 Although the effect of bolus administration of corticosteroids to normal subjects has been reported to depress immunological function ${ }^{32}{ }^{33}$, the result of chronic administration of these drugs is largely unknown and needs to be assessed. ${ }^{34}$

It has been reported that preincubation of mononuclear cells may abrogate the effect of cell bound inhibitors. ${ }^{1316}$ In studies of patients with VH and $\mathrm{CAH}^{16}$ and Hodgkin's disease ${ }^{15}$ depressed Tlymphocyte rosette formation had reverted to normal when tested after preincubation. Likewise, this procedure resulted in enhanced lymphoproliferation in SLE ${ }^{1314}$ and Hodgkins' disease. ${ }^{15}$

In the experiments described in this paper the viral hepatitis patients demonstrated improved mitogen responsiveness after preincubation which was similar to the control group. This finding of only normal enhancement suggests that the factors involved in mitogen hyporesponsiveness in viral hepatitis are not reversible in vitro and this would argue against a role for short-lived suppressor cells ${ }^{17}$ or elutable cell bound inhibitors. ${ }^{14}$ However, the $\mathrm{CAH}$ patients demonstrated an enhancement significantly greater than the control subjects. This exaggerated enhancement may follow the neutralisation of serum inhibitor factors as described by Wernet et al. ${ }^{14}$ or occur because the inhibitor had a short biological half life, as is the case with the rosette inhibitory factor described by Chisari and Edgington. ${ }^{16}$

The enhanced mitogen responsiveness observed in normal subjects after preincubation of their cells has been previously reported. ${ }^{17235}$ It has been proposed that this is due to the loss of a suppressor cell subpopulation, ${ }^{17}$ similar to that described in the mouse by Dutton..$^{36}$ Interpreted in this manner, it is possible that excessive suppressor cell activity is present in CAH and, when this influence is diminished by incubation of these cells, an exaggerated enhancement phenomenon results. This concept is supported by the recent finding of increased numbers of $\mathrm{T}$ gamma cells in $\mathrm{CAH}^{37} \mathrm{~T}$ gamma cells, which contain receptor sites for the Fc portion of IgG are considered to include the suppressor $\mathrm{T}$ cell population. $^{38}$

These two explanations of exaggerated responsiveness in CAH could be unified if it were shown that the mitogen inhibitory factors described in $\mathrm{CAH}$ were the products of suppressor cells. Although there is no firm information about the source of origin or chemical nature of mitogen inhibitors in VH or $\mathrm{CAH},{ }^{3-5}$ it has been suggested that suppressor cells and their products play a role in the immuno-suppression observed in virus diseases. ${ }^{39} 40$

These results confirm the presence of mitogen hyporesponsiveness in viral hepatitis which is independent of extrinsic serum influences and appears to be due to a primary defect in lymphoproliferation. Such a finding is in keeping with depressed cell mediated immunity which has been observed in many other virus diseases ${ }^{40}$ Although the CAH patients responded normally to direct mitogen stimulation, the enhanced responsiveness after cellular preincubation suggested that inhibitory influences were also present in these patients. It is not known whether these inhibitors were derived from suppressor cells or if they are contained in previously described inhibitor factors.

\section{References}

${ }^{1}$ Willems FTC, Melnick JL, Rawls WE. Viral inhibition of the phytohemagglutinin response of human lymphocytes and application to viral hepatitis. Proc Soc Exp Biol (NY) 1969; 130: 652-61.

${ }^{2}$ Agarwal SS, Blumberg BS, Gerstley BJS, London WT, Millman I, Sutnick AI, Loeb LA. Lymphocyte transformation and hepatitis. I. Impairment of thymidine incorporation and DNA polymerase activity. Proc Soc Exp Biol (NY) 1971 ; 137: 1498-502.

${ }^{3}$ Newble DI, Holmes KT, Wangel AG, Forbes IJ. Immune reactions in acute viral hepatitis. Clin Exp Immunol 1975; 20: 17-28.

${ }^{4}$ Wands JR, Perrotto JL, Alpert E, Isselbacher KJ. Cell mediated immunity in acute and chronic hepatitis. J Clin Invest 1975; 55: 921-9.

${ }^{5}$ Brattig N, Berg PA. Serum inhibitory factors (SIF) in patients with acute and chronic hepatitis and their clinical significance. Clin Exp Immunol 1976; 25: 40-9.

${ }^{6}$ Newberry WM, Shorey JW, Sanford JP, Combes B. Depression of lymphocyte reactivity to phytohaemagglutinin by serum from patients with liver disease. Cell Immunol 1973; 6: 87-97.

${ }^{7}$ Giustino V, Dudley FJ, Sherlock S. Thymus-dependent lymphocyte function in patients with hepatitis-associated antigen. Lancet 1972; 2: 850-3.

${ }^{8}$ Nielsen JO, Reinicke V, Dietrichson O, Andersen V, Thomsen M, Andersen E. Immunological studies in Australia antigen carriers with and without liver disease. Clin Exp Immunol 1973; 15: 9-16.

${ }^{9}$ Thestrup-Pedersen $\mathbf{K}$, Ladefoged $\mathrm{K}$, Andersen $\mathbf{P}$. Lymphocyte transformation test with liver-specific protein and phytohaemagglutinin in patients with liver disease. Clin Exp Immunol 1976; 24 : 1-8.

${ }^{10}$ Pettigrew NM, Goudie RB, Russell RI, Chaudhuri AKR. Evidence for a role of hepatitis virus $B$ in chronic alcoholic liver disease. Lancet 1972: 2: 724-5.

${ }^{11}$ Pappas A, Von Seebach HB, Schwarze G, et al. Phytohaemagglutinin-induced lymphocyte transformation and histologic findings in patients with chronic aggressive hepatitis before and during immunosuppressive 
therapy. Beitr Path 1975; 156: 197-207.

${ }^{12}$ Toh BH, Roberts-Thompson IC, Matthews JD, Whittingham S, Mackay IR. Depression of cellmediated immunity in old age and the immunopathic diseases, lupus erythematosus, chronic hepatitis and rheumatoid arthritis. Clin Exp Immunol 1973; 14: 193-202.

${ }^{13}$ Horwitz DA, Garrett MA, Craig AH. Serum effects on mitogenic reactivity in subjects with systemic lupus erythematosus, rheumatoid arthritis and scleroderma. Technical considerations and lack of correlation with anti-lymphocyte antibodies. Clin Exp Immunol 1977; 27: 100-10.

${ }^{14}$ Wernet P, Thoburn R, Moore A, Kunkel HG. Blockage of responder and stimulator lymphocyte surface structures, and the shedding phenomenon mediated by human anti-lymphocyte sera in tissue culture: Lymphocyte recognition and effector mechanisms. In: Lindahl K, Kiessling, Osoba D, eds. Proceedings of the Eighth Leucocyte Culture Conference 1974; New York: Academic Press, 1974: 543-52.

${ }^{15}$ Fuks Z, Strober S, King DP, Kaplan HS. Reversal of cell surface abnormalities of $\mathrm{T}$ lymphocytes in Hodgkin's disease after in vitro incubation in fetal sera. J Immunol 1976; 117: 1331.

${ }^{16}$ Chisari FV, Routenberg JA, Fiala M, Edgington TS. Extrinsic modulation of human T-lymphocyte ERosette function associated with prolonged hepatocellular injury after viral hepatitis. J Clin Invest 1977; 59: $134-42$.

${ }^{17}$ Bresnihan B, Jasin HE. Suppressor function of peripheral blood mononuclear cells in normal individuals and in patients with systemic lupus erythematosus. J Clin Invest 1977; 59: 106-16.

${ }^{18}$ Malavé I, Layrisse Z, Layrisse M. Dose-dependent hyporeactivity to phytohaemagglutinin in systemic lupus erythematosus. Cell Immunol 1975; 15: 231-6.

${ }^{19}$ MacSween RNM, Galbraith I, Thomas MA, Watkinson G, Ludlam GB. Phytohaemagglutinin (PHA) induced lymphocyte transformation and Toxoplasma gondii antibody studies in primary biliary cirrhosis. Evidence of impaired cell mediated immunity. Clin Exp Immunol $1973 ; 15: 35-42$.

${ }^{20}$ Hosking CS, Fitzgerald MG, Simons MJ. Quantified deficiency of lymphocyte response to phytohaemagglutinin in immune deficiency diseases. Clin Exp Immunol 1971; 9: 467-76.

${ }^{21}$ Scheuer PJ. Liver biopsy interpretation 2 nd ed. London: Baillière Tindall, 1973.

${ }^{22}$ Sherlock S. Diseases of the liver and biliary system. Oxford: Blackwell, 1975.

${ }^{23}$ Feighery C, Whelan CA, Weir DG, Greally JF. In vitro studies of suppressor cell function in human peripheral blood mononuclear cells. Clin Exp Immunol 1978; 32: 459-65.

${ }^{24}$ Böyum A. Isolation of mononuclear cells and grannulocytes from human blood. Scand J Clin Lab Invest 1968; 21 : suppl 97: 77-89.

${ }^{25}$ Mellstedt $\mathrm{H}$. In vitro activation of human $\mathrm{T}$ and $\mathrm{B}$ lymphocytes by pokeweed mitogen. Clin Exp Immunol 1975; 19: 75-82.

${ }^{26}$ Paronetto F, Popper $\mathrm{H}$. Two immunologic reactions in the pathogenesis of hepatitis? $N$ Engl J Med 1976; 294: 606-7.

${ }^{27}$ Wright $\mathrm{R}$. Comparison of $\mathrm{HBsAg}$ positive and negative cases: clinical and immunological distinctions. In: Eddleston ALWF, Weber JCP, Williams R., eds. Immune reactions in liver disease. Pitman Medical, 1979: 86. ${ }^{28}$ Doniach D. Heterogeneity within the HBsAg negative group. In: Eddleston ALWF, Weber JCP, Williams $\mathrm{R}$, eds. Immune reactions in liver disease: Pitman Medical, 1979: 121.

${ }^{29}$ Penhale WJ, Farmer A, MacCuvish AC, Irvine WJ. A rapid micro-method for the phyto-haemagglutinininduced lymphocyte transformation test. Clin Exp Immunol 1974; 18: 155-67.

${ }^{30} \mathrm{Graybill}$ JR, Alford RH. Variability of sequential studies of lymphocyte blastogenesis in normal adults. Clin Exp Immunol 1976; 25: 28-35.

${ }^{31}$ Dehoratius RJ, Henderson C, Strickland RG. Lymphocyto-toxins in acute and chronic hepatitis. Characterization and relationships to changes in circulating $T$ lymphocytes. Clin Exp Immunol 1976; 26: 21-7.

${ }^{32}$ Yu DTY, Clements PJ, Paulus HE, Peter JB, Levy J, Barnett EV. Human lymphocyte subpopulations. Effect of corticosteroids. J Clin Invest 1974; 53: 565-71.

${ }^{33}$ Fauci, AS, Dale DC. The effect of in vivo hydrocortisone on sub-populations of human lymphocytes. J Clin Invest $1974 ;$ 53: 240-6.

${ }^{34}$ Saxon A, Stevens RH, Ramer SJ, Clements PJ, Yu DTY. Glucocorticoids administered in vivo inhibit human suppressor $\mathrm{T}$ lymphocyte function and diminish B lymphocyte responsiveness in in vitro immunoglobulin synthesis. J Clin Invest 1978; 61 : 922-30.

${ }^{35}$ Dwyer JM. Failure of concanavalin-A-stimulated lymphocytes to suppress responsiveness to PHA and allogeneic cells as a marker of disordered immunoregulation. In: Lucas DO, ed Regulatory mechanisms New York and London: Academic Press, 1977: 773${ }^{35}$ Dwyer JM. Failure of concanavalin-A-stimulated lymphocytes to suppress responsiveness to PHA and allogeneic cells as a marker of disordered immunoregulation: In: Lucas DO, ed. Regulatory mechanisms in lymphocyte activation, New York and London: Academic Press, 1977: 773-5.

${ }^{36}$ Dutton RW. Inhibitory and stimulatory effects of concanavalin-A of the response of mouse spleen cell suspensions to antigen. I. Characterization of the inhibitory cells activity. $J$ Exp Med 1972; 136: 1445-60.

${ }^{37}$ Wansbrough-Jones MH, Scullard GH, Nicholson A, Eddleston ALWF, Williams R. Lymphocytes forming stable E-rosettes in acute and chronic hepatitis. Clin Exp Immunol 1979; 35: 390-6.

${ }^{38}$ Moretta L, Webb SR, Grossi CE, Lydyard PM, Cooper MD. Functional analysis of two human T-cell subpopulations: help and suppression of B-cell responses by T-cells bearing receptors for IgM or IgG. J Exp Med 1977; 146: 184-200.

${ }^{39}$ Kantor FS. Infection, Anergy and cell mediated immunity. N Engl J Med 1975; 292: 629-34.

${ }^{40}$ Woodruff JF, Woodruff JJ. The effect of viral infections on the function of the immune system. In: Notkins AL, ed. Viral immunology and immunopathology New York: Academic Press, 1975 : 393-418. 